\title{
Reviewing immunosuppressive regimens in animal models for vascularized composite allotransplantation
}

\author{
Aline Yen Ling Wang', Charles Yuen Yung Loh ${ }^{2}$ \\ ${ }^{1}$ Center for Vascularized Composite Allotransplantation, Chang Gung Memorial Hospital, Taoyuan 333, Taiwan. \\ ${ }^{2}$ St Andrew's Center for Burns and Plastic Surgery, Chelmsford CM1 7TH, UK.
}

Correspondence to: Dr. Aline Yen Ling Wang, Center for Vascularized Composite Allotransplantation, Chang Gung Memorial Hospital, 5, Fu-Hsing Street, Gueishan, Taoyuan 333, Taiwan. E-mail: aline2355@yahoo.com.tw

How to cite this article: Wang AYL, Loh CYY. Reviewing immunosuppressive regimens in animal models for vascularized composite allotransplantation. Plast Aesthet Res 2018;5:10. http://dx.doi.org/10.20517/2347-9264.2017.90

Received: 4 Dec 2017 First Decision: 25 Feb 2018 Revised: 6 Mar 2018 Accepted: 7 Mar 2018 Published: 13 Mar 2018

Science Editor: Raman C. Mahabir Copy Editor: Jun-Yao Li Production Editor: Cai-Hong Wang

\begin{abstract}
The development of vascularized composite allotransplantation (VCA) and its clinical need has led to the need for more animal models to study and perform the research required to further this specialty in terms of functional recovery and immunomodulatory improvements. Much of the animal models are reported in individual series in the literature but there has not been a review as such of these models. Here we present a compilation of the animal models reported in the literature thus far in VCA. A comprehensive review of the literature was performed for any studies which involved the use of animal models in various aspects of VCA research. The models were organized according to the type of VCA transplant, whether they were orthotopic or heterotopic, immunosuppressive regimen each study used and investigation purpose. Twenty-one facial transplant models were reported, 3 abdominal wall transplants, 4 penile transplantations, 21 uterus transplantations, 12 hindlimb transplantations and 4 myocutaneous flap transplantation animal models were reported. Primates, swine, rats, mice, rabbits, sheep and dog animal models in VCA were also reported. The most used immunosuppressive drugs are calcineurin inhibitor such as cyclosporin A and tacrolimus in these VCA animal models. They can significantly suppress lymphocyte function by blocking the phosphatase activity of calcineurin of lymphocytes. They are sometimes used combined with mycophenolate mofetil or steroids or antilymphocyte serum. The review of existing animal models will allow further research to be focused in other areas of VCA where there is a current paucity of literature. The immunosuppressive regimens used in each animal model can also be reviewed to determine which regimen works in which type of animal model which will save time and resources for future research.
\end{abstract}

Keywords: Animal models, vascularized composite allotransplantation, immunosuppressive regimens

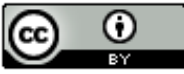

(C) The Author(s) 2018. Open Access This article is licensed under a Creative Commons Attribution 4.0 International License (https://creativecommons.org/licenses/by/4.0/), which permits unrestricted use, sharing, adaptation, distribution and reproduction in any medium or format, for any purpose, even commercially, as long as you give appropriate credit to the original author(s) and the source, provide a link to the Creative Commons license, and indicate if changes were made.

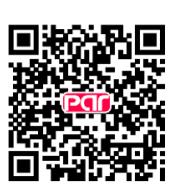




\section{INTRODUCTION}

Vascularized composite allotransplantation (VCA) is an up and coming clinical modality in the realm of reconstructive microsurgery. Being able to replace tissues like for like en bloc is absolutely crucial and empowers the surgeon to achieve the most optimal outcome. However, the greater goal of VCA is the ability of the reconstructive surgeon to not only restore form but also function. Functional restoration could arguably be the epitome of reconstruction where the quality of lives are improved not only from external appearance but rather also allow the patients to get back to their activities of daily living.

Trauma remains a significant burden in today's society with many resulting in soft tissue defects. Other causes of soft tissue defects include congenital deformities and neoplastic conditions. Much of the previous methods for reconstruction include prosthesis or sequential flaps that obliterate and attempted to restore the form of a tissue defect. However, this is often inadequate and is lacking in function. VCA differs from solid organ transplantation (SOT) where tissues of varying antigenicity are transplanted en bloc. This results in issues of varying rejection rates. In particular, skin which is often a component of VCA transplants such as the hand and face has the highest antigenicity of all body tissue types ${ }^{[1]}$. As such, rejection faced by skin component is high and the recipient or patient is dependent on a high constant level of immunosuppression. Skin contains dendritic cells such as Langerhans cells that have strong immunogenic properties and it has been shown that some of these cells of donor origin reside in the epidermis decades after the transplantation ${ }^{[2]}$.

Chronic immunosuppression itself carries deleterious effects in the long run. Patients face opportunistic infections and an increased risk of malignancy from the decreased immunity that is usually present to prevent and take on a surveillance role. As such, one has to carefully weigh up the pro and cons when deciding the perform VCA on a patient. The patient should also be able to finance a lifelong requirement of immunosuppressive drugs which are often costly and have a high dropout rate due to the side effects.

Much of the research at present in VCA is on better improving the safety profile of such procedures, especially with the need for the improvement in immunosuppressive regimens. By decreasing our reliance on immunosuppressive drugs, we increase the acceptability of such a procedure as the downside of immunosuppression can be deleterious. The ultimate goal in transplant science would be to achieve allograft tolerance. Tolerance to an allograft is a phenomenon where the recipient body does not recognize the foreign antigens from the donor and hence will accept the graft. Immunosuppressive drugs can hence be reduced or even omitted. In order for this process to occur, immunological manipulation and re-education of the recipient's immune system has to occur. Several strategies already show promise in this respect and will be discussed in this article. Varying tissue types also have varying levels of inducibility with regards to tolerance formation. In particular, due to the varying tissue types of differing antigenicity in VCA, tolerance is often difficult to achieve.

\section{A brief history of VCA}

VCA has come a long way since its first conception back in AD 348. It has always been a goal of mankind to be able to replace like with like where allograft transplantation en bloc of a gangrenous leg of an elder church sacristan was performed by two brothers known as the miracle of Cosmas and Damian ${ }^{[3]}$. Previously known as composite tissue allotransplantation (CTA), VCA in the past started off with transplantation between identical twins which obviated the need for immunosuppression, which is the bane of VCA and is a focus of intense research at present.

The first-hand allotransplantation was performed in 1964 in Ecuador where a first generation drug regimen was provided. This included steroids and azathioprine initially. However, the hand allograft still was rejected 2 weeks later. Allografted tendons had been performed using non-vascularized techniques to replace lost or nonfunctional upper extremity flexor tendons but end results were unacceptable due to the lack of viability 
of the grafts resulting in rupture as well. With the limited knowledge in immunological manipulation and the adverse effects that happened, further VCA cases were put on hold. It was not until the discovery and development of cyclosporin A during kidney transplantation that it was applied to VCA in the 1980s where immunosuppression finally became more effective. The first successful hand transplant then was carried out in 1998 in France. However, the patient refused to adhere to the immunosuppressive regimen due to personal reasons and compliance issues and hence the arm was again amputated almost 3 years after surgery. The first vascularized tendons were performed by Guimberteau et al. ${ }^{[4]}$ where two allotransplantations of digital flexor tendon apparatus were collected from a living nonrelated donor and from a deceased donor. The tendons were then revascularized using the recipient's ulna vessels and ultimately received acceptable using multiple doses of cyclosporin $\mathrm{A}^{[5]}$. The first successful face transplant occurred in $2005^{[6]}$ and since then, several countries have followed suit.

\section{An overview of clinical VCA cases to date}

Only a few specialized centers in the world with the capability and infrastructure for performing a VCA procedure. As such, an important source of data is the International Registry on Hand and Composite Tissue Transplantation (IRHCTT), which is a voluntary registry that collects clinical information on VCAs. The most recent report of the IRHCTT was published in 2010 and provides follow-up data on 49 hand transplants in 33 patients. Thus far, there have been 89 hand transplants performed since 1998. The United States currently has the largest number of cases, followed by China and Poland.

\section{TYPES OF VCA ANIMAL MODELS REPORTED}

\section{Face transplant models}

A variety of animal models have been used in VCA experiments with the majority being orthotopic face transplants. The animal models were performed in animals such as primates, swine, sheep, canine, rabbit, rats and mice. Different compositions of face allograft comprising of bone, nerve and soft tissue in each animal model have been reported in the literature which has varying levels of antigenicity. As such, each report has used varying types of immunosuppression, which is also dependent on the response of each animal type and to the type of immunosuppressive drug. The transplantation of each allograft can be considered orthotopic if the graft replaces the original site of the donor, i.e., the face, or heterotopic if the allograft is placed in a distant site different from the original area. Orthotopic transplants in these animal models are mostly for assessing not only the rejection process but also the functional restoration of the allograft. Heterotopic allografts, however, are used more for assessing the degree of rejection but normally do not carry an assessment of functional recovery.

In a primate model, heterotopic transfer of a facial transplant including the mandible was transferred from MHC mismatched M fascicularis monkeys. Anti-thymocyte globulin (ATG) was used as an induction regimen with tacrolimus and rapamycin in combination as a maintenance regimen.

Two reports using swine and sheep models were used with facial allografts including bone. However, no immunosuppression was used in these models and was more for the surgical technique of producing such models.

Four canine models were used in mismatched donors to beagle dog recipients. All reports were orthotopic and involved a hemifacial transplantation. With these reports, 2 reports utilized cyclosporine and steroids as maintenance immunosuppression. Two other reports used tacrolimus as maintenance immunosuppression and with 1 report using tacrolimus only for 7 days. One report in a rabbit model used a face and scalp transplantation model with no immunosuppression. 
Eleven rat animal models for face transplant were reported in the literature. Nine of the reports were allografts and 2 were syngeneic. Ten reports were orthotopically transferred and 1 with heterogenic transplantation. Various face transplant components were reported ranging from ear, scalp, face, mystacial pad or mandible with tongue transplantation. A combination of cyclosporin A or tacrolimus was used in these animal models. Four of these reports had nerve coaptation which looked at the functional recovery in allograft especially using mystacial pad transplantation.

Two reports of murine orthotopic face transplant were reported with either a hemiface or ear allograft. No immunosuppressive regimens were used in these reports with more focus on the surgical technique of transferring an ear or hemiface. The information is presented in Table 1.

\section{Abdominal wall transplantation models}

Abdominal wall transplantation comprising of various tissue types also constitutes a vascularized composite allotransplantation model. All reported models thus far have been carried out in rats across MHC mismatched rats from Brown-Norway to Lewis rats. The abdominal wall transplants were orthotopic with 2 hemi-abdominal wall transplants and 1 with the inclusion of a hindlimb transplant. One report had a total abdominal wall allograft transplanted. Anti-lymphocyte serum was used in 2 of the reports for induction therapy. Two reports utilized cyclosporine and 1 in combination with adipocyte derived stem cells intravenously. The models do not include all nerve anastomoses and mixed chimerism all at once. The information is presented in Table 2.

\section{Penile transplantation models}

Penile allograft transplantation models have been described in four articles, all of which have been performed in rats. Two studies were syngeneic rats, 1 of which was orthotopic and 1 heterotopic. These studies were focused on the surgical model and being syngeneic grafts, no immunosuppression was used. Anastomosis of the penile artery and vein was key in each model and ensuring the conduit of the urethra was restored. The other 2 studies used allografts and heterotopically transplanted penile grafts. One of the studies used tacrolimus and the other cyclosporin A. The information is presented in Table 3.

\section{Uterus transplantation models}

Uterus transplantation has been touted as a method of restoring fertility but functionally must perform as required. Three articles report uterus transplantations in primates, 7 in sheep, 2 in rabbits, 6 in rats and 3 in murine models. The function of the transplanted uterus was tested in rabbits, rats and mice which were successful in 3 of the studies. In primate uterus transplantation, various types of immunosuppressive regimens were used including tacrolimus, mycophenolate mofetil and methylprednisolone as maintenance regimes. Another protocol utilized ATG as an induction agent followed by tacrolimus and corticosteroids as maintenance. The information is presented in Table 4.

\section{Hindlimb transplantation models}

Hindlimb transplantation has been a model to mimic hand transplantation where components of bone, muscle, nerve, fat and skin are included in a hindlimb. The animal models demonstrated here to explore the feasibility of modulating the immunosuppressive regimen in improving the viability of hindlimb transplants. When transplanted orthotopically, they also serve as a model to assess the functional recovery of the hindlimb when used for gait. The nerve recovery is crucial in improving the function of the transplanted allograft. The information is presented in Table 5 .

\section{Myocutaneous tissue transplantation models}

Soft tissue alone with varying tissue types including fat, connective tissue and muscle are collectively known as myocutaneous flaps in free flap transplantation. The varying antigenicity of the tissue types is what constitutes 
Table 1. Facial animal models

\begin{tabular}{|c|c|c|c|c|c|}
\hline & Allo-transplantation & Approach & Graft & Regimen & References \\
\hline Primate & $\begin{array}{l}\text { Mismatched donor to recipient } \\
\text { M. fascicularis monkey }\end{array}$ & Heterotopic & Mandibular OMC & $\begin{array}{l}\text { ATG (10 to } 20 \mathrm{mg} / \mathrm{kg} / \text { day) induction with } \\
\text { tacrolimus }(0.2 \text { to } 0.1 \mathrm{mg} / \mathrm{kg} / \text { day) and } \\
\text { rapamycin ( } 0.05 \text { incresased to } 0.2 \mathrm{mg} / \mathrm{kg} / \text { day) } \\
\text { maintenance }\end{array}$ & [7] \\
\hline Swine & Pig autotransplant & Orthotopic & $\begin{array}{l}\text { Le-Fort-based } \\
\text { maxilloface }\end{array}$ & No immunosuppression & {$[8]$} \\
\hline Sheep & $N / A$ & $N / A$ & Hemifacial and auricle & $N / A$ & [9] \\
\hline Canine & Mongrel to Beagle dog & Orthotopic & Hemiface and scalp & $\begin{array}{l}\mathrm{CSA}(6-18 \mathrm{mg} / \mathrm{kg} / \text { day }) \text { and steroid } \\
\text { methylprednisolone }(4-8 \mathrm{mg} / \mathrm{kg} / \text { day })\end{array}$ & {$[10]$} \\
\hline Canine & $\begin{array}{l}\text { Mismatched donor to recipient } \\
\text { Beagle dog }\end{array}$ & Orthotopic & Hemiface and scalp & Tacrolimus $2 \mathrm{mg} / \mathrm{kg} /$ day for 7 days & [11] \\
\hline Canine & $\begin{array}{l}\text { Mismatched donor to recipient } \\
\text { Beagle dog }\end{array}$ & Orthotopic & Hemiface & CSA (4 mg/kg/day) & {$[12]$} \\
\hline Canine & $\begin{array}{l}\text { Mismatched donor to recipient } \\
\text { Beagle dog }\end{array}$ & Orthotopic & Mandibular hemijoint & Tacrolimus 1 mg/kg/day maintenance & [13] \\
\hline Rabbit & NZB to NZW & Orthotopic & Facial and scalp & No immunosuppression & [14] \\
\hline Rat & BN to LEW & Orthotopic & Mystacial pad & $\begin{array}{l}\text { CSA } 16 \mathrm{mg} / \mathrm{kg} \text { on POD } 1-14,13 \mathrm{mg} / \mathrm{kg} \text { on POD } \\
15-80 \text {, then } 10 \mathrm{mg} / \mathrm{kg} \text { maintenance }\end{array}$ & {$[15]$} \\
\hline Rat & $B N$ to $L E W$ & Orthotopic & Face and scalp & $\begin{array}{l}\mathrm{CSA} 16 \mathrm{mg} / \mathrm{kg} / \mathrm{day} \text {, tapered to } 2 \mathrm{mg} / \mathrm{kg} \text { in } 4 \\
\text { weeks and maintained }\end{array}$ & {$[16]$} \\
\hline Rat & LEW syngeneic & Heterotopic & $\begin{array}{l}\text { Hemiface with mandible } \\
\text { and Tongue }\end{array}$ & No immunosuppression & [17] \\
\hline Rat & BN to LEW & Orthotopic & Auricle & $\begin{array}{l}\mathrm{CSA} 16 \mathrm{mg} / \mathrm{kg} / \text { day for } \\
2 \text { weeks and tapered to } 8 \mathrm{mg} / \mathrm{kg} / \text { day for } 2 \\
\text { weeks }\end{array}$ & {$[18]$} \\
\hline Rat & BN to LEW & Orthotopic & $\begin{array}{l}\text { Hemifacial with } \\
\text { mystacial region }\end{array}$ & $\begin{array}{l}\text { Tacrolimus } 8 \mathrm{mg} / \mathrm{kg} / \text { day, tapered to } \\
2 \mathrm{mg} / \mathrm{kg} / \text { day in } 4 \text { weeks }\end{array}$ & [19] \\
\hline Rat & BN to Wistar & Orthotopic & Hemiface & $\begin{array}{l}\text { CSA } 16 \text { mg/kg/day for } 7 \text { days, tapered to } 2 \\
\mathrm{mg} / \mathrm{kg} / \text { day for } 23 \text { days }\end{array}$ & [20] \\
\hline Rat & BN to LEW & Orthotopic & Auricle & $\begin{array}{l}\text { CSA } 16 \mathrm{mg} / \mathrm{kg} / \text { day in first week, tapered to } \\
8 \mathrm{mg} / \mathrm{kg} / \text { day and maintained for } 2 \text { weeks, then } \\
4 \mathrm{mg} / \mathrm{kg} \text { maintained }\end{array}$ & {$[21]$} \\
\hline Rat & LEW syngeneic & Orthotopic & Ear & No immunosuppression & [22] \\
\hline Rat & Lew-BN to Wistar-Lew & Orthotopic & Mystacial pad & $\begin{array}{l}\text { Tacrolimus } 6 \mathrm{mg} / \mathrm{kg} / \text { day in first week, tapered } \\
\text { to } 4 \mathrm{mg} / \mathrm{kg} / \text { day in second week, then } \\
2 \mathrm{mg} / \mathrm{kg} / \text { day maintained }\end{array}$ & [23] \\
\hline Rat & Lew-BN to LEW & Orthotopic & $\begin{array}{l}\text { Hemiface with ear and } \\
\text { scalp }\end{array}$ & $\begin{array}{l}\text { CSA } 16 \mathrm{mg} / \mathrm{kg} / \text { day in first week, tapered to } \\
2 \mathrm{mg} / \mathrm{kg} / \text { day over } 4 \text { weeks and maintained }\end{array}$ & [24] \\
\hline Rat & BN to LEW & $\begin{array}{l}\text { Orthotopic } \\
\text { and } \\
\text { heterotopic }\end{array}$ & Hemiface and scalp & $\begin{array}{l}\text { CSA } 8 \mathrm{mg} / \mathrm{kg} \text { on POD } 1-2,6 \mathrm{mg} / \mathrm{kg} \text { on POD } 3-6, \\
4 \mathrm{mg} / \mathrm{kg} \text { on POD } 7-30,2 \mathrm{mg} / \mathrm{kg} \text { on POD } 31-42\end{array}$ & [25] \\
\hline Murine & $\mathrm{BALB} / \mathrm{c}$ to $\mathrm{B} 6$ & Orthotopic & $\begin{array}{l}\text { Myocutaneous } \\
\text { hemiface }\end{array}$ & No immunosuppression & {$[26]$} \\
\hline Murine & $\mathrm{BALB} / \mathrm{c}$ to $\mathrm{B} 6$ & Orthotopic & Ear & No immunosuppression & {$[27]$} \\
\hline
\end{tabular}

NZW: New Zealand White; NZB: New Zealand Black; BN: Brown Norway; LEW: Lewis; B6: C57BL/6; CSA: cyclosporin A; ATG: anti-thymocyte globulin; OMC: osteomyocutaneous; POD: postoperative day; N/A: not available

Table 2. Abdominal wall animal models

\begin{tabular}{|c|c|c|c|c|c|}
\hline & Allo-transplantation & Approach & Graft & Regimen & References \\
\hline Rat & BN to LEW & Orthotopic & Hemi-abdominal & $\begin{array}{l}\text { ALS } 2.5 \text { mg induction, each CSA 16, } 10 \text { and } 5 \\
\mathrm{mg} / \mathrm{kg} / \text { day for } 10 \text { days }\end{array}$ & {$[28]$} \\
\hline Rat & BN to LEW & Orthotopic & Total abdominal wall & Tacrolimus 0.5 mg/kg/day maintained & [29] \\
\hline Rat & BN to LEW & $\begin{array}{l}\text { Orthotopic and } \\
\text { heterotopic }\end{array}$ & $\begin{array}{l}\text { Hemi-abdominal with } \\
\text { hindlimb }\end{array}$ & $\begin{array}{l}\text { ALS } 2.5 \mathrm{mg} \text { induction, CSA } 16 \mathrm{mg} / \mathrm{kg} / \text { day for } \\
10 \text { days and } 3 \text { doses of ADSC }\left(2 \times 10^{6}\right)\end{array}$ & {$[30]$} \\
\hline
\end{tabular}

BN: Brown Norway; LEW: Lewis; CSA: cyclosporin A; ALS: antilymphocyte serum; ADSC: adipose-derived stem cell

the unique response directed against vascularized composite allotransplantations. Two swine models were reported with the use of gracillis myocutaneous flaps and fasciocutaneous flap transfers. One study had no immunosuppression and another had total body radiation with cyclosporin A maintenance therapy. One study utilized the transfer of the rectus abdominus myocutaneous flaps in syngeneic beagles without any immunosuppression as a model. One study utilized a combination of heart transplantation with an abdominal 
Table 3. Penile animal models

\begin{tabular}{lllll}
\hline & Allo-transplantation & \multicolumn{1}{c}{ Approach } & Graft & \multicolumn{1}{c}{ Regimen } \\
\hline Rat & SD19 autotransplant & Original rgion & Penis & No immunosuppression \\
Rat & SD19 autotransplant & Transferred to groin region & Penis & No immunosuppression \\
Rat & BN to LEW & Heterotopic & Penis & Tacrolimus 0.6 mg/kg/day maintained \\
Rat & Lew-BN to LEW & Heterotopic & Penis & CSA $16 \mathrm{mg} / \mathrm{kg} /$ day tapered to $2 \mathrm{mg} / \mathrm{kg} / \mathrm{day}$ in \\
& & & 4 weeks, then maintained & [33] \\
\hline
\end{tabular}

BN: Brown Norway; LEW: Lewis; CSA: cyclosporin A; SD 19: Sprague-Dawely rats

Table 4. Uterus animal models

\begin{tabular}{|c|c|c|c|c|c|}
\hline & Allo-transplantation & Approach & Graft & Regimen & References \\
\hline Primate & $\begin{array}{l}\text { M. fascicularis monkey } \\
\text { autotransplant }\end{array}$ & & Uterus & No immunosuppression & [35] \\
\hline Primate & $\begin{array}{l}\text { Mismatched M. fascicularis } \\
\text { monkey }\end{array}$ & Orthotopic & Uterus & $\begin{array}{l}\text { Tacrolimus } 0.3 \mathrm{mg} / \mathrm{kg} / \text { day, MMF } 20-10 \\
\mathrm{mg} / \mathrm{kg} / \text { day, and methylprednisolone } \\
10-2 \mathrm{mg} / \text { day maintained }\end{array}$ & [36] \\
\hline Primate & Mismatched olive baboons & Orthotopic & Uterus & $\begin{array}{l}\text { ATG } 10 \mathrm{mg} / \mathrm{kg} \text { induction, followed by tacrolimus } \\
0.1 \mathrm{mg} / \mathrm{kg} / \mathrm{day} \text {, Corticosteroids } 60-5 \mathrm{mg} / \mathrm{kg} \text { and } \\
\text { MMF } 50 \mathrm{mg} / \mathrm{kg}\end{array}$ & [37] \\
\hline Sheep & $\begin{array}{l}\text { Swedish wool sheep } \\
\text { autotransplant }\end{array}$ & Orthotopic & Uterus & No immunosuppression & {$[38]$} \\
\hline Sheep & Sheep autotransplant & & Uterus & No immunosuppression & [39] \\
\hline Sheep & Sheep autotransplant & Orthotopic & Uterus & No immunosuppression & \\
\hline Sheep & Mismatched sheep & Heterotopic & Whole uterus & No immunosuppression & {$[40]$} \\
\hline Sheep & Mismatched Romney marsh sheep & Orthotopic & Uterus & $\begin{array}{l}\text { CSA 2-5 mg/kg/day maintained and prednisone } \\
2 \mathrm{mg} / \mathrm{kg} / \text { day for } 2 \text { weeks }\end{array}$ & {$[41]$} \\
\hline Sheep & Mismatched sheep & Orthotopic & Uterus & $\begin{array}{l}\text { ATG } 50 \mathrm{mg} \text { induction, followed by tacrolimus } \\
0.02 \mathrm{mg} / \mathrm{kg} / \text { day, methylprednisolone } 40 \mathrm{mg} / \\
\text { day and MMF } 1.5 \mathrm{~g} / \text { day }\end{array}$ & {$[42]$} \\
\hline Sheep & Mismatched limousine sheep & Orthotopic & Uterus & $\begin{array}{l}\text { CSA } 10 \mathrm{mg} / \mathrm{kg} / \text { day and MMF } 3 \mathrm{~g} / \text { day, both on } \\
\text { POD } 7,14,28,42,56, \text { methylprednisolone } \\
40 \mathrm{mg} \text { on POD } 1-7\end{array}$ & [43] \\
\hline Rabbit & NZW allotransplant & Orthotopic & Uterus & $\begin{array}{l}\text { Prednisolone } 10 \text { mg was given for } 3 \text { days } \\
\text { following the "spikes" alongside an increase in } \\
\text { tacrolimus dose from } 500 \text { to } 1 \mathrm{~g} \text { twice/day }\end{array}$ & [39] \\
\hline Rabbit & Mismatched NZW & Orthotopic & Uterus & $\begin{array}{l}\text { Tacrolimus } 500 \times \text { g twice daily postoperatively; } \\
\text { embryo transfer }\end{array}$ & {$[44]$} \\
\hline Rat & LEW syngeneic & Heterotopic & Uterus & No immunosuppression & [45] \\
\hline Rat & LEW syngeneic & Orthotopic & Uterus & No immunosuppression & {$[46]$} \\
\hline Rat & $\mathrm{BN}$ to $\mathrm{DA}$ & Heterotopic & $\begin{array}{l}\text { Whole uterus } \\
\text { and ovaries }\end{array}$ & No immunosuppression & {$[47]$} \\
\hline Rat & BN to LEW & Orthotopic & Uterus & CSA $10 \mathrm{mg} / \mathrm{kg} /$ day maintained & [48] \\
\hline Rat & BN to LEW & Orthotopic & Uterus & Tacrolimus $0.5 \mathrm{mg} / \mathrm{kg} /$ day pump maintained & [49] \\
\hline Rat & Virgin Dark Agouti to virgin LEW & Orthotopic & Uterus & $\begin{array}{l}\text { Tacrolimus } 0.5 \mathrm{mg} / \mathrm{kg} / \text { day maintained; male SD } \\
\text { rats of proven fertility were used for mating }\end{array}$ & {$[50]$} \\
\hline Murine & $\begin{array}{l}\text { F1-hybrids of inbred female } \\
\text { C57BL/6 X CBA/ca syngeneic }\end{array}$ & Heterotopic & $\begin{array}{l}\text { Right uterine } \\
\text { horn and the } \\
\text { cervix }\end{array}$ & $\begin{array}{l}\text { No immunosuppression; } \\
\text { embryo transfer }\end{array}$ & {$[51]$} \\
\hline Murine & B6 syngeneic & Orthotopic & Ovarian & No immunosuppression & {$[52]$} \\
\hline Murine & $\begin{array}{l}\text { F1-hybrids of } \mathrm{C} 57 \mathrm{BL} / 6 \times \mathrm{CBA} / \mathrm{ca} \\
\text { to } \mathrm{B} 6\end{array}$ & Heterotopic & $\begin{array}{l}\text { Right uterine } \\
\text { horn and the } \\
\text { cervix }\end{array}$ & CSA $20 \mathrm{mg} / \mathrm{kg} /$ day & [53] \\
\hline
\end{tabular}

BN: Brown Norway; LEW: Lewis; CSA: cyclosporin A; DA: Sprague-Dawley; MMF: mycophenolate mofetil; NZW: New Zealand White

musculocutaneous flap. The combination of two models is particularly interesting which confers a high degree of morbidity in the animal. In the rat study, maintenance was carried out with cyclosporin A after the inclusion of the heart transplantation. The information is presented in Table 6.

\section{CONCLUSION}

The summary of the findings in this article demonstrates the various VCA models reported in the literature before. In order to carry our further experiments and determine the future of allotransplantation, animal models summarized in this article will hopefully shed light on the future directions for research and where 
Table 5. Hindlimb animal models

\begin{tabular}{|c|c|c|c|c|c|}
\hline & Allo-transplantation & Approach & Graft & Regimen & References \\
\hline Primate & $\begin{array}{l}\text { Mismatched donor to } \\
\text { recipient } M \text {. fascicularis } \\
\text { monkey }\end{array}$ & Orthotopic & $\begin{array}{l}\text { Sensate osteomyocutaneous } \\
\text { radial forearm flap }\end{array}$ & $\begin{array}{l}\text { Tacrolimus } 1 \mathrm{mg} / \mathrm{kg} \text { and mycophenolate } \\
\text { mofetil } 20 \mathrm{mg} / \mathrm{kg} \text {; } \\
\text { both every } 12 \text { hour, methylprednisolone } \\
15 \mathrm{mg} / \mathrm{kg} \text { for } 3 \text { days followed by } \\
7.5 \mathrm{mg} / \mathrm{kg} \text { for } 2 \text { days and a } 50 \% \\
\text { reduction every } 2 \text { days until the dose was } \\
1 \mathrm{mg} / \mathrm{kg}\end{array}$ & {$[54]$} \\
\hline Swine & White pig autotransplant & Heterotopic & Whole forelimb & No immunosuppression & {$[55]$} \\
\hline Swine & Mismatched newborn swine & Heterotopic & Newborn knee & No immunosuppression & [56] \\
\hline Swine & $\begin{array}{l}\text { Mismatched donor to } \\
\text { recipient pigs }\end{array}$ & Heterotopic & $\begin{array}{l}\text { Skeletal graft consisting of } \\
\text { the tibia, fibula, knee joint, } \\
\text { distal femur, and surrounding } \\
\text { muscles }\end{array}$ & No immunosuppression & {$[57]$} \\
\hline Swine & $\begin{array}{l}\text { Mismatched donor to } \\
\text { recipient pigs }\end{array}$ & Orthotopic & $\begin{array}{l}\text { Osteomyocutaneous forearm } \\
\text { flap }\end{array}$ & No immunosuppression & {$[58]$} \\
\hline Swine & $\begin{array}{l}\text { Mismatched donor to } \\
\text { recipient pigs }\end{array}$ & Orthotopic & $\begin{array}{l}\text { Radial forelimb } \\
\text { osteomyocutaneous flap }\end{array}$ & No immunosuppression & {$[59]$} \\
\hline Rabbit & NZW autotransplant & Orthotopic & Whole knee joint & No immunosuppression & {$[60]$} \\
\hline Rat & $\mathrm{N} / \mathrm{A}$ & $\mathrm{N} / \mathrm{A}$ & $\begin{array}{l}\text { Cremaster } \\
\text { muscle and pubic bone flap }\end{array}$ & $\mathrm{N} / \mathrm{A}$ & {$[61]$} \\
\hline Rat & $\mathrm{ACl}$ to WF & Heterotopic & $\begin{array}{l}\text { Hindlimb } \\
\text { osteomyocutaneous }\end{array}$ & $\begin{array}{l}\text { TBI } 600 \text { cGy prior to } 1 \text { dose of BMC } 100 \\
\times 10^{6} \text { cells } / \mathrm{kg} \text { with tacrolimus } \\
1 \mathrm{mg} / \mathrm{kg} / \text { day for } 10 \text { days and ALS } \\
5 \mathrm{mg} \text { on POD10 }\end{array}$ & {$[62]$} \\
\hline Rat & WF to LEW & Orthotopic & $\begin{array}{l}\text { Simultaneous dual-surgeon } \\
\text { hindlimb }\end{array}$ & No immunosuppression & {$[63]$} \\
\hline Rat & BN to LEW & Orthotopic & Vascularized elbow & $\begin{array}{l}\text { CSA } 16 \mathrm{mg} / \mathrm{kg} / \text { day for first week, tapered } \\
\text { to } 2 \mathrm{mg} / \mathrm{kg} / \text { day, then maintenance }\end{array}$ & {$[64]$} \\
\hline Rat & Lewis-BN to LEW & Orthotopic & IBOMC flap & $\begin{array}{l}\text { CSA } 16 \mathrm{mg} / \mathrm{kg} / \text { day in } 1 \text { st week, tapered } \\
\text { to } 8 \mathrm{mg} / \mathrm{kg} / \mathrm{day} \text { in } 2 \mathrm{nd} \text { week, to } 4 \mathrm{mg} / \\
\mathrm{kg} / \mathrm{day} \text { in } 3 \mathrm{rd} \text { week and to } 2 \mathrm{mg} / \mathrm{kg} / \mathrm{day} \\
\text { in } 4 \text { th week and maintained }\end{array}$ & {$[65]$} \\
\hline
\end{tabular}

NZW: New Zealand White; BN: Brown Norway; LEW: Lewis; CSA: cyclosporin A; POD: postoperative day; N/A: not available; WF: WistarFurth; BMC: bone marrow cells; IBOMC: iliac bone osteomusculocutaneous

Table 6. Myofasciocutaneous animal models

\begin{tabular}{|c|c|c|c|c|c|}
\hline & Allo-transplantation & Approach & Graft & Regimen & References \\
\hline Swine & $\begin{array}{l}\text { Mismatched donor to } \\
\text { recipient MGH miniature } \\
\text { swine }\end{array}$ & Heterotopic & $\begin{array}{l}\text { Gracilis myocutaneous } \\
\text { flap }\end{array}$ & No immunosuppression & {$[66]$} \\
\hline Swine & $\begin{array}{l}\text { Mismatched donor to } \\
\text { recipient MGH miniature } \\
\text { swine }\end{array}$ & Heterotopic & Fasciocutaneous flap & $\begin{array}{l}\text { TBI } 100 \mathrm{cGy} \text { and CD3-IT conditioning prior to } 3 \\
\text { doses of HCT } 15 \times 10^{9} \text { cells } / \mathrm{kg} \text { with CSA (target } \\
\text { trough } 400-800 \mathrm{ng} / \mathrm{mL} \text { ) for } 45 \text { days }\end{array}$ & {$[67]$} \\
\hline Canine & Beagles autotransplant & $\begin{array}{l}\text { Transferred to groin } \\
\text { region }\end{array}$ & $\begin{array}{l}\text { Myocutanenous rectus } \\
\text { flap }\end{array}$ & No immunosuppression & {$[68]$} \\
\hline Rat & $\begin{array}{l}\text { WKY heart and LEW VCA to } \\
\text { F344 }\end{array}$ & $\begin{array}{l}\text { Heterotopic heart and } \\
\text { orthotopic VCA }\end{array}$ & $\begin{array}{l}\text { Heart and abdominal } \\
\text { musculocutaneous flap }\end{array}$ & $\begin{array}{l}\text { CSA } 5 \mathrm{mg} / \mathrm{kg} / \text { day every other day for } \\
10 \text { days after heart transplant }\end{array}$ & [69] \\
\hline
\end{tabular}

LEW: Lewis; CSA: cyclosporin A; TBI: total body irradiation; CD3-IT: CD3-immunotoxin; HCT: hematopoietic cell transplantation; F344: Fischer 344; WKY: Wistar Kyoto

further focus can be emphasized. Experimental animal surgical models can be difficult to perform and such research in VCA should be best collaborated with both clinicians and surgeons who can perform the difficult animal models, as well as basic scientists to further developments in this specialty.

Many of the immunosuppressive regimens used thus far involve an induction agent such as anti-thymocyte globulin or total body radiation which preconditions the host's immune system in preparation for a chance of engraftment of donor antigens. In particular, the phenomenon of chimerism is particularly seen in VCA research where the transfer of vascularized bone marrow, in long bones in particular, mediates a constant exchange of cells such as regulatory $\mathrm{T}$ cells which serve to protect the allograft. A particular preference for cyclosporin A, tacrolimus and steroids were seen across each animal model - quite so due to their widespread 
availability and immunosuppressive capabilities. They mediate and protect the allograft from being attacked by host defense mechanisms which would destroy the graft otherwise.

\section{DECLARATIONS}

\section{Authors' contributions}

Wang AYL and Loh CYY were both involved in data collection, drafting of the manuscript, analysis of data, the second review of data, statistical analysis, ensuring data fidelity and manuscript review.

\section{Financial support and sponsorship}

None.

\section{Conflicts of interest}

There are no conflicts of interest.

\section{Patient consent}

Not applicable.

\section{Ethics approval}

Not applicable.

\section{Copyright}

(c) The Author(s) 2018.

\section{REFERENCES}

1. Murray JE. Organ transplantation (skin, kidney, heart) and the plastic surgeon. Plast Reconstr Surg 1971;47:425-31.

2. Thaunat O, Badet L, Dubois V, Kanitakis J, Petruzzo P, Morelon E. Immunopathology of rejection: do the rules of solid organ apply to vascularized composite allotransplantation? Curr Opin Organ Transplant 2015;20:596-601.

3. Kahan BD. Cosmas and Damian revisited. Transplant Proc 1983;15:2211-6.

4. Guimberteau JC, Baudet J, Panconi B, Boileau R, Potaux L. Human allotransplant of a digital flexion system vascularized on the ulnar pedicle: a preliminary report and 1-year follow-up of two cases. Plast Reconstr Surg 1992;89:1135-47.

5. Petit F, Minns AB, Dubernard JM, Hettiaratchy S, Lee WP. Composite tissue allotransplantation and reconstructive surgery: first clinical applications. Ann Surg 2003;237:19-25.

6. Dubernard JM, Lengelé B, Morelon E, Testelin S, Badet L, Moure C, Beziat JL, Dakpé S, Kanitakis J, D’Hauthuille C, El Jaafari A, Petruzzo P, Lefrancois N, Taha F, Sirigu A, Di Marco G, Carmi E, Bachmann D, Cremades S, Giraux P, Burloux G, Hequet O, Parquet N, Francès C, Michallet M, Martin X, Devauchelle B. Outcomes 18 months after the first human partial face transplantation. $N$ Engl J Med 2007;357:2451-60.

7. Silverman RP, Banks ND, Detolla LJ, Shipley ST, Panda A, Sanchez RA, Azimzadeh AM, Pierson RN 3rd, Wang D, Rodriguez ED, Holton LH 3rd, Bartlett ST. A heterotopic primate model for facial composite tissue transplantation. Ann Plast Surg 2008;60:209-16.

8. Santiago GF, Susarla SM, Al Rakan M, Coon D, Rada EM, Sarhane KA, Shores JT, Bonawitz SC, Cooney D, Sacks J, Murphy RJ, Fishman EK, Brandacher G, Lee WP, Liacouras P, Grant G, Armand M, Gordon CR. Establishing cephalometric landmarks for the translational study of Le Fort-based facial transplantation in Swine: enhanced applications using computer-assisted surgery and custom cutting guides. Plast Reconstr Surg 2014;133:1138-51.

9. Uygur S, Ozturk C, Kwiecien G, Djohan R, Siemionow M. Sheep hemifacial and auricular transplantation models: an anatomic study. Ann Plast Surg 2014;72:469-74.

10. Shengwu Z, Qingfeng L, Hao J, Banich J, Kaiding F, Benson C, Huiyong W, Danning Z, Bing G, Qinxiu L, Lujia T, Tao Z, Yuping L, Tisheng Z. Developing a canine model of composite facial/scalp allograft transplantation. Ann Plast Surg 2007;59:185-94.

11. Lee KM, Eun SC. Experimental canine facial transplantation. Transplant Proc 2014;46:1208-11.

12. Eduardo Bermú Dez L, Santamaría A, Romero T, Calderó DF. Experimental model of facial transplant. Plast Reconstr Surg 2002;110:1374-5.

13. Höhnke C, Russavage JM, Subbotin V, Llull R, Starzl TE, Sotereanos GC. Vascularized composite tissue mandibular transplantation in dogs. Transplant Proc 1997;29:995.

14. Baek RM, Eun SC, Heo CY, Chang H. Experimental facial transplantation surgery. J Craniofac Surg 2010;21:648-51.

15. Washington KM, Solari MG, Sacks JM, Horibe EK, Unadkat JV, Carvell GE, Simons DJ, Lee WP. A model for functional recovery and cortical reintegration after hemifacial composite tissue allotransplantation. Plast Reconstr Surg 2009;123:S26-33.

16. Ulusal BG, Ulusal AE, Ozmen S, Zins JE, Siemionow MZ. A new composite facial and scalp transplantation model in rats. Plast Reconstr Surg 2003;112:1302-11.

17. Kulahci Y, Siemionow M. A new composite hemiface/mandible/tongue transplantation model in rats. Ann Plast Surg 2010;64:114-21.

18. Ulusal AE, Ulusal BG, Hung LM, Wei FC. Establishing a composite auricle allotransplantation model in rats: introduction to transplantation of facial subunits. Plast Reconstr Surg 2005;116:811-7.

19. Landin L, Cavadas PC, Gonzalez E, Rodriguez JC, Caballero A. Functional outcome after facial allograft transplantation in rats. J Plast Reconstr 
Aesthet Surg 2008;61:1034-43.

20. Climov M, Măciuceanu Zarnescu MB, Stefănescu A, Zamfirescu D, Lascăr I. Learning curve in hemifacial transplantation in rats. Chirurgia (Bucur) 2013;108:234-40.

21. Ulusal BG, Ulusal AE, Wei FC. Long-term outcomes of composite auricle as a neurosensorial facial subunit allotransplant. Ann Plast Surg 2009;62:311-6.

22. Chiu DT, Ascherman JA, Patsis MC. Rat ear transplantation: a feasibility study. J Reconstr Microsurg 1993;9:33-8.

23. Landin L, Cavadas PC, Gonzalez E, Caballero-Hidalgo A, Rodriguez-Perez JC. Sensorimotor recovery after partial facial (mystacial pad) transplantation in rats. Ann Plast Surg 2009;63:428-35.

24. Demir Y, Ozmen S, Klimczak A, Mukherjee AL, Siemionow M. Tolerance induction in composite facial allograft transplantation in the rat model. Plast Reconstr Surg 2004;114:1790-801.

25. Ramirez AE, Lao WW, Wang YL, Cheng HY, Wei FC. Two-stage face transplantation: a new concept in vascularized composite allotransplantation. Microsurgery 2015;35:218-26.

26. Sucher R, Lin CH, Oberhuber R, Kern B, Zheng XX, Zelger B, Pratschke J, Schneeberger S, Lee WP, Brandacher G. Hemiface allotransplantation in the mouse. Plast Reconstr Surg 2012;129:867-70.

27. Jiang J, Humar A, Gracia B, Zhong R. Surgical technique for vascularized ear transplantation in mice. Microsurgery 1998;18:42-6.

28. Lao WW, Wang YL, Ramirez AE, Cheng HY, Wei FC. A new rat model for orthotopic abdominal wall allotransplantation. Plast Reconstr Surg Glob Open 2014;2:e136.

29. Quigley MA, Fletcher DR, Zhang W, Nguyen VT. Development of a reliable model of total abdominal wall transplantation. Plast Reconstr Surg 2013;132:988-94

30. Ramirez AE, Cheng HY, Lao WW, Wang YL, Wen CJ, Wallace CG, Lin CF, Shih LY, Chuang SH, Wei FC. A novel rat full-thickness hemiabdominal wall/hindlimb osteomyocutaneous combined flap: influence of allograft mass and vascularized bone marrow content on vascularized composite allograft survival. Transpl Int 2014;27:977-86.

31. Seyam RM, Kattan SA, Assad LW, El-Sayed RM, Almohanna FH. Penile autotransplantation in rats: an animal model. Urol Ann 2013;5:255-8.

32. Akyurek M, Ozkan O, Safak T, Ozgentas HE, Dunn RM. The penile flap in the rat: description and autotransplantation. Ann Plast Surg 2005;55:94-100; discussion 101.

33. Koga H, Yamataka A, Wang K, Kato Y, Lane GJ, Kobayashi H, Sueyoshi N, Miyano T. Experimental allogenic penile transplantation. J Pediatr Surg 2003;38:1802-5.

34. Sonmez E, Nasir S, Siemionow M. Penis allotransplantation model in the rat. Ann Plast Surg 2009;62:304-10.

35. Kisu I, Banno K, Mihara M, Hara H, Umene K, Adachi M, Nogami Y, Aoki D. A surgical technique using the ovarian vein in non-human primate models of potential living-donor surgery of uterus transplantation. Acta Obstet Gynecol Scand 2015;94:942-8.

36. Kisu I, Mihara M, Banno K, Hara H, Masugi Y, Araki J, Iida T, Yamada Y, Kato Y, Shiina T, Suganuma N, Aoki D. Uterus allotransplantation in cynomolgus macaque: a preliminary experience with non-human primate models. J Obstet Gynaecol Res 2014;40:907-18

37. Johannesson L, Enskog A, Mölne J, Diaz-Garcia C, Hanafy A, Dahm-Kähler P, Tekin A, Tryphonopoulos P, Morales P, Rivas K, Ruiz P, Tzakis A, Olausson M, Brännström M. Preclinical report on allogeneic uterus transplantation in non-human primates. Hum Reprod 2013;28:189-98.

38. Wranning CA, Dahm-Kähler P, Mölne J, Nilsson UA, Enskog A, Brännström M. Transplantation of the uterus in the sheep: oxidative stress and reperfusion injury after short-time cold storage. Fertil Steril 2008;90:817-26.

39. Saso S, Petts G, David AL, Thum MY, Chatterjee J, Vicente JS, Marco-Jimenez F, Corless D, Boyd M, Noakes D, Lindsay I, Del Priore G, Ghaem-Maghami S, Smith JR. Achieving an early pregnancy following allogeneic uterine transplantation in a rabbit model. Eur J Obstet Gynecol Reprod Biol 2015;185:164-9.

40. Gonzalez-Pinto IM, Tryphonopoulos P, Avison DL, Nishida S, Tekin A, Santiago S, Tzakis AG. Uterus transplantation model in sheep with heterotopic whole graft and aorta and cava anastomoses. Transplant Proc 2013;45:1802-4.

41. Ramirez ER, Ramirez DK, Pillari VT, Vasquez H, Ramirez HA. Modified uterine transplant procedure in the sheep model. J Minim Invasive Gynecol 2008;15:311-4

42. Wei L, Xue T, Yang H, Zhao GY, Zhang G, Lu ZH, Huang YH, Ma XD, Liu HX, Liang SR, Yang F, Chen BL. Modified uterine allotransplantation and immunosuppression procedure in the sheep model. PLoS One 2013;8:e81300.

43. Gauthier T, Bertin F, Fourcade L, Maubon A, Saint Marcoux F, Piver P, Marquet P, Pommepuy I, Plainard X, Couquet C, Cornuejols MJ, Essig M, Aubard Y. Uterine allotransplantation in ewes using an aortocava patch. Hum Reprod 2011;26:3028-36.

44. Saso S, Hurst S, Chatterjee J, Kuzmin E, Thum Y, David AL, Hakim N, Corless DJ, Boyd M, Noakes DE, Lindsay I, Ghaem-Maghami S, Del Priore G, Smith JR. Test of long-term uterine survival after allogeneic transplantation in rabbits. J Obstet Gynaecol Res 2014;40:754-62.

45. Wranning CA, Akhi SN, Kurlberg G, Brännström M. Uterus transplantation in the rat: model development, surgical learning and morphological evaluation of healing. Acta Obstet Gynecol Scand 2008;87:1239-47.

46. Díaz-García C, Akhi SN, Martínez-Varea A, Brännström M. The effect of warm ischemia at uterus transplantation in a rat model. Acta Obstet Gynecol Scand 2013;92:152-9.

47. Jiga LP, Lupu CM, Zoica BS, Ionac M. Experimental model of heterotopic uterus transplantation in the laboratory rat. Microsurgery 2003;23:246-50.

48. Groth K, Akhi SN, Mölne J, Wranning CA, Brännström M. Effects of immunosuppression by cyclosporine A on allogenic uterine transplant in the rat. Eur J Obstet Gynecol Reprod Biol 2012;163:97-103.

49. Akhi SN, Diaz-Garcia C, El-Akouri RR, Wranning CA, Mölne J, Brännström M. Uterine rejection after allogeneic uterus transplantation in the rat is effectively suppressed by tacrolimus. Fertil Steril 2013;99:862-70.

50. Díaz-García C, Akhi SN, Wallin A, Pellicer A, Brännström M. First report on fertility after allogeneic uterus transplantation. Acta Obstet Gynecol Scand 2010;89:1491-4.

51. Racho El-Akouri R, Kurlberg G, Dindelegan G, Mölne J, Wallin A, Brännström M. Heterotopic uterine transplantation by vascular anastomosis in the mouse. J Endocrinol 2002;174:157-66.

52. Parkening TA, Collins TJ, Elder FF. Orthotopic ovarian transplantations in young and aged C57BL/6J mice. Biol Reprod 1985;32:989-97.

53. Wranning CA, El-Akouri RR, Groth K, Mölne J, Parra AK, Brännström M. Rejection of the transplanted uterus is suppressed by cyclosporine A in a semi-allogeneic mouse model. Hum Reprod 2007;22:372-9.

54. Cendales LC, Xu H, Bacher J, Eckhaus MA, Kleiner DE, Kirk AD. Composite tissue allotransplantation: development of a preclinical model in nonhuman primates. Transplantation 2005;80:1447-54

55. Kiermeir DM, Meoli M, Müller S, Abderhalden S, Vögelin E, Constantinescu MA. Evaluation of a porcine whole-limb heterotopic autotransplantation model. Microsurgery 2013;33:141-7. 
56. Solla F, Pan H, Watrelot D, Leveneur O, Dubernard JM, Gazarian A. Composite tissue allotransplantation in newborns: a swine model. J Surg Res 2013;179:e235-43.

57. Kuo YR, Sacks JM, Lee WP, Wu WS, Kueh NS, Yao SF, Chiang YC. Porcine heterotopic composite tissue allograft transplantation using a large animal model for preclinical studies. Chang Gung Med J 2006;29:268-74.

58. Ren X, Shirbacheh MV, Ustüner ET, Zdichavsky M, Edelstein J, Maldonado C, Breidenbach WC, Frank J, Tobin GR, Jones JW, Barker JH. Osteomyocutaneous flap as a preclinical composite tissue allograft: swine model. Microsurgery 2000;20:143-9.

59. Ustüner ET, Majzoub RK, Ren X, Edelstein J, Maldonado C, Perez-Abadia G, Breidenbach WC, Barker JH. Swine composite tissue allotransplant model for preclinical hand transplant studies. Microsurgery 2000;20:400-6.

60. Kremer T, Giusti G, Friedrich PF, Willems W, Bishop AT, Giessler GA. Knee joint transplantation combined with surgical angiogenesis in rabbits--a new experimental model. Microsurgery 2012;32:118-27.

61. Ogur S, Cinar C, Ozturk C, Yildirim I. A new composite flap model in the rat: combined cremaster muscle and pubic bone flap. Ann Plast Surg 2008;60:692-7.

62. Adamson LA, Huang WC, Breidenbach WC, Rahhal D, Xu H, Huang Y, Pidwell DJ, Wei FC, Tobin G, Ildstad ST. A modified model of hindlimb osteomyocutaneous flap for the study of tolerance to composite tissue allografts. Microsurgery 2007;27:630-6.

63. Sacks JM, Kuo YR, Horibe EK, Hautz T, Mohan K, Valerio IL, Lee WP. An optimized dual-surgeon simultaneous orthotopic hind-limb allotransplantation model in rats. J Reconstr Microsurg 2012;28:69-75.

64. Tang J, Zhu H, Luo X, Li Q, Levin LS, Tintle SM. A vascularized elbow allotransplantation model in the rat. J Shoulder Elbow Surg 2015;24:779-86.

65. Nasir S, Klimczak A, Sonmez E, Bozkurt M, Gibson S, Siemionow M. New composite tissue allograft model of vascularized bone marrow transplant: the iliac osteomyocutaneous flap. Transpl Int 2010;23:90-100.

66. Leto Barone AA, Leonard DA, Torabi R, Mallard C, Glor T, Scalea JR, Randolph MA, Sachs DH, Cetrulo CL Jr. The gracilis myocutaneous free flap in swine: an advantageous preclinical model for vascularized composite allograft transplantation research. Microsurgery 2013;33:51-5.

67. Leonard DA, Kurtz JM, Mallard C, Albritton A, Duran-Struuck R, Farkash EA, Crepeau R, Matar A, Horner BM, Randolph MA, Sachs DH, Huang CA, Cetrulo CL Jr. Vascularized composite allograft tolerance across MHC barriers in a large animal model. Am J Transplant 2014; $14: 343-55$.

68. Mathes DW, Noland M, Graves S, Schlenker R, Miwongtum T, Storb R. A preclinical canine model for composite tissue transplantation. $J$ Reconstr Microsurg 2010;26:201-7.

69. Yang J, Erdmann D, Chang JC, Komatsu I, Zhang Y, Wang D, Hodavance MS, Hollenbeck ST, Levinson H, Klitzman B, Levin LS. A model of sequential heart and composite tissue allotransplant in rats. Plast Reconstr Surg 2010;126:80-6. 